\title{
Tinjauan Etik Pembukaan Rahasia Medis dan Identitas Pasien pada Situasi Wabah Pandemi COVID-19 dan Kaitannya dengan Upaya Melawan Stigma Pasien Positif
}

\author{
Rulliana Agustin', Anna Rozaliyani ${ }^{2,3}$, Ghina Faradisa Hatta, Pukovisa Prawiroharjo ${ }^{2,4}$ \\ 'Departemen Pendidikan Kedokteran Fakultas Kedokteran Universitas Indonesia \\ ${ }^{2}$ Majelis Kehormatan Etik Kedokteran Pengurus Besar Ikatan Dokter Indonesia \\ ${ }^{3}$ Departemen Parasitologi Fakultas Kedokteran Universitas Indonesia \\ ${ }^{4}$ Departemen Neurologi Fakultas Kedokteran Universitas Indonesia/Rumah Sakit Cipto Mangunkusumo
}

\begin{abstract}
Kata Kunci
Pembukaan rahasia medis, identitas pasien, pandemi covid-19, stigma

Korespondensi

pukovisa@ui.ac.id

Publikasi

(C) 2020 JEKI/ilmiah.id

DOI

Io.26880/jeki.v4i2.46

Tanggal masuk: 21 Mei 2020

Tanggal ditelaah: 24 Agustus 2020

Tanggal diterima: 28 Agustus 2020

Tanggal publikasi: 4 September 2020

Abstrak Surveilans kesehatan masyarakat merupakan hal dasar yang perlu dilaksanakan pada kejadian wabah penyakit menular. Akan tetapi, pembukaan rahasia medis yang dikumpulkan pada kondisi wabah (termasuk nama, alamat, diagnosis, riwayat keluarga, dan sebagainya) tanpa persetujuan pasien dapat berisiko bagi individu yang bersangkutan. Penanganan data tersebut perlu dilakukan secara hatihati karena individu terkait dapat menghadapi stigmatisasi maupun diskriminasi bila informasi terkait dirinya, terutama data dengan hasil tes positif, bocor ke publik. Maka dari itu, pengaturan dan panduan penggunaan pembukaan rahasia medis dalam kondisi wabah penyakit menular memerlukan pendalaman etik yang baik. Terdapat beberapa peraturan dan panduan yang mengatur kerahasiaan pasien dalam kondisi wabah. Regulasi hukum serupa pun juga ditemukan pada negara lainnya, seperti Amerika Serikat dan Inggris.
\end{abstract}

\begin{abstract}
Public health surveillance is needed in any infectious disease outbreak. However, disclosing medical secrets collected in an outbreak (including name, address, diagnosis, family history, etc.) without the patient's consent can pose a risk to the individual. The handling of this information needs to be done carefully because the individual concerned can face stigmatization or discrimination if their information, especially in confirmed patients, is leaked to the public. Therefore, the regulations and guidelines for the use of medical disclosures in conditions of infectious disease outbreaks require a deep ethical discourse. There are several regulations which assist the confidentiality of patients in epidemic conditions. Similar regulations are also found in other countries, such as the United States and the United Kingdom.
\end{abstract}

Dalam menyikapi pandemi Coronavirus Disease (COVID-19) yang tengah merebak tentunya diperlukan pengambilan keputusan yang dituntut cepat, meskipun bukti untuk pengambilan keputusan tersebut masih sedikit dan sumber daya yang tersedia terbatas. Observasi dan pengumpulan data yang sistematis menjadi komponen yang esensial dalam langkah penanganan, baik sebagai panduan manajemen di waktu sekarang maupun di masa yang akan datang. Mengacu pada Undang-Undang (UU) Nomor 4 Tahun 1984 tentang Wabah Penyakit Menular ${ }^{1}$ dan UU Nomor 36 Tahun 2009 tentang Kesehatan², salah satu upaya penanggulangan wabah yang harus dilakukan adalah penyelidikan epidemiologis atau surveilans kesehatan oleh pemerintah. Penyelenggaraan surveilans dengan pola kedaruratan pada wabah pun diatur pada Keputusan Menteri Kesehatan Republik Indonesia Nomor 1116/Menkes/SK/VII/2003 tentang Pedoman Penyelenggaraan Sistem Surveilans Epidemiologi Kesehatan. ${ }^{3}$ Walaupun surveilans kesehatan masyarakat merupakan hal yang mendasar dan wajib dilakukan pada kejadian wabah penyakit menular, hal tersebut harus diikuti dengan pendalaman etik yang baik. Salah satunya adalah terkait pembukaan rahasia medis dan identitas pasien serta dampaknya terhadap stigma di masyarakat.

\section{Kewajiban perlindungan rahasia medis pada kondisi wabah}

Rahasia medis mengikat hubungan dokter dan pasien dengan didasari oleh berbagai peraturan. Sumpah Dokter Indonesia butir 4 
menyatakan bahwa "Saya akan merahasiakan segala sesuatu yang saya ketahui karena keprofesian saya". ${ }^{4}$ Hal itu ditegaskan oleh Kode Etik Kedokteran Indonesia Tahun 2012 (Kodeki) pada Pasal 16 yang menyatakan "Setiap dokter wajib merahasiakan segala sesuatu yang diketahuinya tentang seorang pasien, bahkan juga setelah pasien itu meninggal dunia" ${ }^{5}$ dan selaras dengan UU No. 29 tahun 2004 tentang Praktik Kedokteran pasal 48 ayat 1 yang menyebutkan "Setiap dokter atau dokter gigi dalam melaksanakan praktik kedokteran wajib menyimpan rahasia kedokteran". ${ }^{6}$ Rahasia kedokteran hanya dapat dibuka apabila ada alasan etik yang kuat dan apabila dilakukanpenuh kehati-hatian. Hal ini juga ditambahkan pada penjelasan Pasal 16 ayat 3 Kodeki yang menjelaskan "Seorang dokter tidak boleh menggunakan rahasia pasiennya untuk merugikan pasien, keluarga atau kerabat dekatnya dengan membukanya kepada pihak ketiga atau yang tidak berkaitan". ${ }^{5}$ Kewajiban menjaga rahasia tersebut juga selaras dengan kaidah dasar bioetika autonomy dan beneficence. Prinsip autonomy berlaku karena pada umumnya penjagaan rahasia tersebut adalah yang diinginkan pasien dan beneficence karena menekankan berbuat baik demi kepentingan pasien.

Mengacu pada Surat Keputusan Majelis Kehormatan Etika Kedokteran Nomor 015/ $\mathrm{PB} / \mathrm{K} . M K E K / 03 / 2020$ tentang Fatwa Etik Kedokteran, Kebijakan Kesehatan, dan Penelitian dalam Konteks Pandemi COVID-19, identitas pasien, dengan atau tanpa gejala, serta kasus positif tetap harus dilindungi. Pada keadaan tertentu, informasi dapat dibuka sebatas inisial nama, jenis kelamin, status kesehatan singkat (meninggal, klinis kritis berat, ataupun sembuh), usia dan kronologis yang relevan terhadap penelusuran penularan. Adapun informasi klinis lainnya yang mendalam, yang tidak ada kepentingan kesehatan masyarakat yang luas, seperti status kesehatan terperinci, penyakit penyerta, dan tatalaksana sebaiknya tidak dibuka. Akan tetapi, hal ini kembali lagi pada pengecualian terhadap ketentuan peraturan perundangundangan yang berlaku, termasuk dalam halnya menyangkut pembukaan nama penjabat publik dan nama tenaga medis yang menjadi korban dapat diberikan penghargaan oleh dunia profesi kedokteran dan negara. ${ }^{?}$

Dengan demikian, pembukaan rahasia medis yang dikumpulkan pada kondisi wabah (termasuk nama, alamat, diagnosis, riwayat keluarga, dan sebagainya) tanpa persetujuan pasien dapat berisiko bagi individu yang bersangkutan. ${ }^{8-10}$ Maka dari itu, organisasi kesehatan dunia (World Health Organization, WHO) menyarankan bahwadibalik kebutuhan negara untuk mengendalikan wabah, negara juga harus memastikan perlindungan yang cukup terhadap risiko tersebut. Hal ini dapat dilakukan dengan memastikan hukum kerahasiaan informasi pada aktivitas surveilans dan penggunaan informasi terbatas hanya untuk tujuan awal dikumpulkannya informasi tersebut. Penggunaan dan pembagian informasi untuk kegiatan selain surveilans maupun riset yang kurang berhubungan, memerlukan pengajuan etik terhadap komite yang bersangkutan. ${ }^{11}$ Untuk keperluan surveilans, pembukaan idedntitas pasien dalam batas tertentu masih dapat diterima, tapi untuk riset tidak bisa diterima karena tidak ada alasan apa pun yang memerlukan pembukaan rahasia identitas subjek penelitian. Seluruh data klinik boleh diungkapkan, kecuali identitas subjek penelitian.

\section{Pembukaan rahasia medis kepada individual dan komunitas}

Telah dituangkan dalam Surat Keputusan Majelis Kehormatan Etika Kedokteran Nomor 015/PB/K.MKEK/03/2020 tentang Fatwa Etik Kedokteran, Kebijakan Kesehatan, dan Penelitian dalam Konteks Pandemi COVID-19, bahwa rahasia medis terkait kepentingan pengumpulan informasi wabah dapat dibuka dalam kondisi dan batasan tertentu. Partisipasi universal masyarakat dalam pengumpulan informasi surveilans kesehatan ini tentu harus diikuti timbal balik dari pemerintah berupa pelaksanaan surveilans yang "transparan". Transparan dalam hal ini berarti pasien juga harus sadar informasi apa saja yang mereka berikan, untuk apa, dan kemungkinan 
pembukaan informasi kepada pihak ketiga. Selain itu, selaras dengan UU Nomor 36 Tahun 2009 tentang Kesehatan Pasal 154, transparan juga merujuk pada kewajiban pemerintah untuk mengumumkan hasil surveilans tersebut secara berkala, yakni mengumumkan jenis dan persebaran penyakit, termasuk daerah yang berpotensi sebagai penularan. Hal ini merupakan hal yang penting demi terjaganya hak kesehatan masyarakat secara keseluruhan di semua wilayah. ${ }^{2}$ Perlu diingat bahwa suatu perbuatan dianggap baik/etis apabila tujuannya baik, dilakukan dengan cara yang baik, disertai dilakukan pada waktu, tempat, dan situasi yang sesuai.

WHO merekomendasikan pembagian data secara cepat (rapid data sharing) terkait kegawatan kesehatan masyarakat. Pada kondisi wabah, yang merupakan keadaan penuh ketidakpastian dan ketidakstabilan, pembagian data berkala menjadi krusial dan mendesak. Data dalam hal ini termasuk surveilans kesehatan, studi riset klinis, studi epidemiologis, kualitatif, maupun lingkungan. Setiap pihak yang berperan harus berkooperasi dalam membagikan data yang relevan dan akurat demi penanggulangan wabah. Keterlibatan data yang banyak tersebut membutuhkan negara untuk menelaah kembali hukum dan kebijakan terkait pembagian data serta kerahasiaannya. Bagi masyarakat, pembagian informasi berkala secara transparan dapat melawan informasi yang salah, menenangkan kepanikan, memulihkan kepercayaan publik, serta mendorong bantuan masyarakat dalam krisis yang sedang terjadidalam kata lain urgensi pembagian data berkala dapat melahirkan respons yang tepat guna. ${ }^{11}$

Selain UU Kesehatan, terdapat beberapa peraturan lainnya yang mendukung transparansi informasi kepada publik dalam kondisi wabah, yakni Pasal 12 Peraturan Komisi Informasi Nomor 1 tahun 2010 tentang Standar Layanan Informasi Publik mewajibkan badan publik yang memiliki kewenangan untuk mengumumkan informasi yang dapat mengancam hajat hidup orang banyak, dalam hal ini termasuk informasi terkait epidemi dan wabah. ${ }^{12}$ Tentunya hal ini juga didukung hak atas kesehatan yang telah dijamin dalam Pasal 4 UU Kesehatan serta Pasal
9 ayat 3 UU Nomor 39 Tahun 1999 tentang Hak Asasi Manusia. 2,13

Melalui hal ini, pembukaan informasi medis tidak hanya terkait pembukaan informasi ke publik, namun juga terkait tujuan surveilans. ${ }^{8}$ Merujuk pada Surat Keputusan MKEK terkait fatwa etik COVID-19, pembukaan informasi medis terbatas pada hal yang relevan terhadap penelusuran penularan, tanpa mengungkap identitas lengkap pasien.? Tentunya, pengungkapan identitas tersebut dapat mendapat pengecualian untuk beberapa tokoh dengan perundang-undangan dan alasan etik yang kuat. Terkait penelitian dan surveilans, pembagian data yang dibutuhkan juga harus melindungi rahasia medis terperinci dan terbatas penggunaannya pada kegiatan yang relevan dan telah disetujui. ${ }^{7,8,14}$

\section{Kebijakan pembukaan rahasia medis terkait surveilans kesehatan di negara lain}

Di Amerika Serikat, rahasia medis dilindungi oleh kebijakan Health Insurance Portability and Accountability Act (HIPAA) tahun 1996 yang dikeluarkan oleh Kantor Hak Sipil (OCR) pada Departemen Kesehatan dan Layanan Kemanusiaan (HHS) Amerika Serikat. Akhir Maret 2020 lalu, Kantor Hak Sipil Amerika Serikat mengeluarkan pernyataan pedoman pembukaan informasi kesehatan terlindungi atau dengan kata lain adalah rahasia medis individu yang telah terinfeksi ataupun berkontak erat dengan penderita COVID-19 kepada penegak hukum, paramedis dan penolong pertama lainnya, serta petugas kesehatan masyarakat terkait Aturan Privasi HIPAA 1996 tersebut. Pembukaan rahasia medis terkait infeksi COVID-19 tanpa persetujuan individu terkait dapat dilakukan secara bertanggung jawab ketika individu tersebut membutuhkan tatalaksana, penolong pertama hendak melakukan penolongan dan berisiko terinfeksi, serta kewajiban melaporkan kasus kepada petugas kesehatan masyarakat berwenang untuk mencegah dan mengontrol penyebaran COVID-19. Akan tetapi, perlu diperhatikan untuk tetap membatasi pembukaan informasi rahasia tersebut pada batas minimum yang mencukupi, terkecuali 
dibutuhkan secara hukum. ${ }^{15}$ Selain itu, Kantor Hak Sipil Amerika Serikat juga mengeluarkan izin dan pedoman dalam penggunaan informasi medis oleh fasilitas kesehatan untuk menginformasikan dan menanyakan kesediaan dalam mendonasikan darah dan plasma untuk aktivitas berbasis populasi terkait peningkatan koordinasi kesehatan, manajemen kasus, dan pelayanan. $^{16}$

Di Inggris dan Wales, terdapat regulasi hukum penggunaan data rahasia pasien yang kompleks. Selain persyaratan UndangUndang Perlindungan Data 1998, terdapat juga kewajiban berdasarkan Common Law Duty of Confidence. Berdasarkan Hukum Inggris, terlepas dari Duty of Confidence sehubungan dengan data pasien, juga terdapat dasar hukum untuk memproses informasi rahasia pasien untuk tujuan kesehatan masyarakat. Hal ini diatur dalam Peraturan Perlindungan Kesehatan (pemberitahuan) tahun 2010 yang memperbolehkan pengesampingan tugas hukum (menjaga rahasia medis) dengan kewajiban hukum (pengendalian wabah) pada praktisi medis dalam notifikasi penyakit menular tertentu dan kontaminasi yang mungkin terjadi kepada otoritas lokal melalui Public Health England (PHE). ${ }^{14}$

\section{Stigmatisasi dan diskriminasi terhadap hasil positif}

Keadaan darurat kesehatan masyarakat, seperti wabah COVID-19 ini, tentu menimbulkan tekanan bagi masyarakat. Ketakutan dan kecemasan terhadap suatu penyakit dapat menyebabkan stigma sosial terhadap orang, tempat, atau hal lain. Tentunya, beberapa kelompok rentan terhadap stigma, seperti, pasien suspek, personel medis, bahkan pasien yang telah dinyatakan sembuh sekalipun. Stigma sosial dapat menimbulkan penolakan sosial, diskriminasi dalam edukasi, pelayanan kesehatan, pekerjaan, hingga menimbulkan kekerasan fisik. ${ }^{17,18}$

Terdapat beberapa hal yang dapat dilakukan untuk melawan stigma dalam respons COVID-19 ini, namun yang paling penting adalah menjaga kerahasiaan identitas pasien sebagai tanggung jawab fasilitas medis dan pemerintah. Tak dapat dipungkiri, di tengah ketidakpastian keadaan wabah, kebutuhan akan informasi dan data menjadi kebutuhan yang mendesak. Seperti yang telah disinggung sebelumnya, perhatian yang cukup perlu diberikan pada bagaimana informasi data tersebut ditangani karena individu terkait dapat menghadapi stigmatisasi ataupun diskriminasi apabila informasi terkait dirinya, terlebih dengan hasil tes positif, bocor kepada publik. ${ }^{11,17}$ Selain dampak negatif pada pasien, dampak lainnya yang perlu dikhawatirkan adalah memberikan rasa malu atau takut akan diskriminasi pada pasien COVID-19 lainnya untuk maju memeriksakan penyakitnya sehingga dapat menyebabkan pemerintah lebih sulit lagi untuk mengendalikan wabah ini. Stigma dapat dilawan dengan mengedukasi masyarakat dan melawan informasi yang salah. ${ }^{11,17,18}$

\section{KESIMPULAN}

Kondisi wabah COVID-19 memerlukan kegiatan surveilans kesehatan sebagai tindakan dasar dalam penanganannya. Dalam prosesnya, informasi data pasien banyak terlibat dan dapat menimbulkan isu etik. Informasi identitas pasien harus tetap dilindungi dan pembukaan informasi medis terbatas pada hal yang relevan terhadap penelusuran penularan. Hal ini dikhawatirkan dapat menimbulkan stigmatisasi di masyarakat dan menambah kesulitan pemerintah dalam mengendalikan wabah. Transparansi pembagian informasi terkait wabah juga menjadi hal yang mendesak dalam kondisi saat ini.

\section{KONFLIK KEPENTINGAN}

Tidak ada konflik kepentingan.

\section{REFERENSI}

1. Undang-Undang Republik Indonsia Nomor 4 Tahun 1984 tentang Wabah Penyakit Menular. Jakarta; 1984. 
2. Undang-Undang Republik Indonesia Nomor 36 Tahun 2009 tentang Kesehatan. 2009.

3. Keputusan Menteri Kesehatan Republik Indonesia Nomor 1116/Menkes/SK/ VII/2003 tentangPedoman Penyelenggaraan Sistem Surveilans Epidemiologi Kesehatan. Menteri Kesehatan Republik Indonesia; 2003.

4. Sumpah Dokter Indonesia. Jakarta; 1984.

5. Majelis Kehormatan Etik Kedokteran Indonesia. Kode etik kedokteran tahun 2012. Jakarta: Majelis Kehormatan Etik Kedokteran Indonesia; 2012.

6. Undang-Undang Republik Indonesia Nomor 29 Tahun 2004 tentang Praktik Kedokteran pasal 37. Jakarta; 2004.

7. Majelis Kehormatan Etik Kedokteran Indonesia. Fatwa Etik Kedokteran, Kebijakan Kesehatan, dan Penelitian dalam Konteks Pandemi COVID-19. Majelis Kehormatan Etik Kedokteran Indonesia; 2020.

8. Nicol TE. Confidentiality versus disclosure of a patient's infectious status. Gen Dent [online serial]. 45:78-80. Accessed at: http:// www.ncbi.nlm.nih.gov/pubmed/9171485.

9. Myers J, Frieden TR, Bherwani KM, Henning KJ. Ethics in Public Health Research. Am J Public Health [online serial]. 2008;98:793-801. Accessed at: http:// ajph.aphapublications.org/doi/10.2105/ AJPH.2006.107706.

10. El Emam K, Mercer J, Moreau K, GravaGubins I, Buckeridge D, Jonker E. Physician privacy concerns when disclosing patient data for public health purposes during a pandemic influenza outbreak. BMC Public Health [online serial]. 2011;11:454. Accessed at: http://bmcpublichealth.biomedcentral. com/articles/10.1186/1471-2458-11-454.
11. World Health Organization. Guidance For Managing Ethical Issues In Infectious Disease Outbreaks [online]. 2016. Accessed at: https://www.who.int/ethics/ publications/infectious-disease-outbreaks/ en/. Accessed April 12, 2020.

12. Peraturan Komisi Informasi Nomor 1 tahun 2010 tentang Standar Layanan Informasi Publik. Jakarta: Komisi Informasi Republik Indonesia; 2010.

13. Undang-Undang Republik Indonesia Nomor 39 Tahun 1999 tentang Hak Asasi Manusia. Jakarta; 1999.

14. Taylor MJ. Legal Bases for Disclosing Confidential Patient Information for Public Health: Distinguishing between Health Protection and Health Improvement: Med Law Rev [online serial]. 2015;23:348-374. Accessed at: https://academic.oup.com/ medlaw/article-lookup/doi/10.1093/ medlaw/fwv018.

15. Office of Civil Rights of U.S. Deparment of Health and Human Services. COVID-19 and HIPAA: Disclosures to law enforcement, paramedics, other first responders and public health authorities [online]. 2020. Accessed at: https://www.hhs.gov/sites/ default/files/covid-19-hipaa-and-firstresponders-508.pdf. Accessed April 12, 2020.

16. Office of Civil Rights of U.S. Deparment of Health and Human Services. Guidance on HIPAA and Contacting Former COVID-19 Patients about Blood and Plasma Donation. 2020.

17. Centers for Disease Control and Prevention. Reducing stigma. 2020.

18. World Health Organization. A guide to preventing and addressing social stigma. 2020. 